\title{
Wherever Something Stands Something Stands Beside It: Ritual Symbols in Isiokpo Religious Thought
}

\author{
George I.K Tasie (Ph.D) \\ Department of Religious and Cultural Studies University of Port Harcourt, Nigeria.
}

\begin{abstract}
This study focuses on ritual symbols among the Isiokpo, a people who occupy the north-eastern fringes of the Niger Delta of Nigeria. The study reveals that symbol in Isiokpo religious thought is a kind of representation, but it is also more than that. When it occurs spontaneously, it can foretell the occurrence of that which it represents. Thus, symbols for the Isiokpo, are not just mere representations or labels. They are seen as capable of affecting the objects they symbolize. In sum, they are seen as having representative, predictive and causal powers.
\end{abstract}

\section{Introduction}

Man is a symbol using animal. His ability to symbolize is an important distinguishing factor which places him higher than other beast. Language may be the most important kind of symbolization, nevertheless, it is no the only one. Religious actions and objects are equally symbolic and indeed impregnated with meanings which may only make sense to a devotee but which an outsider could find difficult to decipher. Thus it is by no means strange that each culture has certain elements which are important to its distinctive organization.

However, unlike animal communication in which the act unquestionably represents the signal, human communication is inherently handicapped by two very important factors. One is the differences in human culture; which is to say that the meaning of any symbol is a matter of culturally established convention. The second is the ambiguity in human behaviour. Human beings can lie hence the occurrence of a signal may not necessarily denote its referent (Roy Rappaport, 1971:57). It is something similar to the latter that aroused my interest in the present study.

I had just arrived in Isiokpo on a certain day and met a group of young boys discussing excitedly. They were very worried and disturbed because some unknown persons had hoisted оти nku (tender palm fronds) on some farmlands belonging to their family. This by implication meant that the said farmlands were in dispute and, therefore, work of any kind was forbidden on them until the matter had been resolved. One of the young boys in the group was so deeply touched that he bemoaned the fate that awaited his family. If the dispute lingered on for a long time this might spell hunger in the following year. In a rural setting like that of the Isiokpo where farmers increasingly require cash from the sales of farm products to pay children's school fees and to meet other demands of life, I readily appreciated the dire implications the hoisting of omu nku could have for the affected family.

Before long, news reached the village head, who commissioned the town-crier to go round and summon the aggrieved party to come forward and begin litigation. For more than to weeks nobody owned up. However, it was later discovered that the оти nku was not hoisted by any aggrieved person but by children who were merely dramatizing adult roles.

\section{My Aim in the Present Study}

Two things attracted my curiosity. The first was the signal which a mere piece of tender palm frond found on one's farmland could convey. The second was the excitement which this generated and the effort at reconciling the parties. On further inquiry, I was confronted with yet a long list of ritual objects, gestures and sayings whose symbolic values were as interesting as that of the omu nku. My aim in the present study is to discuss some of these objects and behaviours found in Isiokpo ritual network and seek their relationship to the people's cosmology, social organizations and values.

\section{The Meaning of Symbol and the Methodology Adopted for this Study}

Symbol is a word which has come to mean different things to different people and which is used in a wide variety of contexts. In the physical sciences, for example, symbols are mere representations of ideas by the use of signs. In literature and art symbols are artistic inventions to express sensually ideas, emotions, and abstractions in place of realism. However, for the purpose of this essay we adopt symbol to mean a thing regarded by general consent as naturally typifying or representing or recalling something, by possession of analogous qualities or by association in fact or thought (V. Turner 1967:15). 
On the other hand a ritual is often viewed as a non rational means (however efficacious for the actors) to achieve culturally defined ends, its symbols are characterized, drawn out highly repetitive human behaviour (E.R. Leach, 1978:229). On a simple note, ritual may be described as all the rites connected with a religious ceremony. Ritual symbols, therefore, are those objects, behaviours, gestures and sayings which feature in rites, and which are employed to enhance the overall aim of the ritual.

In this study I used three indicators which enabled me to identify which events or objects among the Isiokpo are considered symbolic and which are not. They are:

i) What the people themselves consider as very important.

ii) $\mathrm{X}$ is likely to feature regularly in different rituals.

iii) There is a sense of awe surrounding $X$ and taboos regarding its usage (adapted from S.B. Ortner, 1973).

Having identified which event or object is symbolic and which is not one other obstacle was in the discovering of the meaning of a symbol. In an attempt to allocate meaning and appropriate interpretation to ritual symbols, I adopted a three-fold methodology.

The first approach was the extensive use of oral testimony. What Victor Turner refers to as "indigenous interpretation" or the "exegetical meaning (V. Turner, 1967: 79).

In this study I utilized two kinds of oral testimony:

i) Reports of believers of their beliefs about ritual objects and behaviours.

ii) Handed down tradition about meanings of ritual objects and behaviours.

Reports of beliefs can normally be taken at face-value, especially when they are produced in explanation of particular concrete situations. Nonetheless, I had to guard against lying, concealment and a typicality by sampling beliefs relating to certain objects and behaviours as widely as possible in order to ascertain which beliefs were typical and which unusual.

I also had to ask about remote happenings; both about earlier accounts of the meaning of certain ritual objects and behaviours. This is where I had to depend on handed down tradition with its notorious sources of distortion. Distortion could be possible through forgetfulness or embellishment for artistic effect, through interaction with other traditions, through innovation to explain what has become obscure or for political gains. However, the intensity of distorting factor is likely to be greatest in the area of socio-political history and less in the area of religious history.

To check distortion, I had to take into account the position of my informant in the society. What cultural organizations did he belong to and what position or title did he hold? Was he culturally rooted to his local community or alienated from the culture and tradition of his people by Western education, civil or mercantile service, or by frequent traveling for various other purposes? Naturally those who were culturally rooted in their local community would be better versed in the tradition of their people than the latter (see E.B Idowu, 1973:82).

I encountered one major problem in the use of oral testimony in the interpretation of symbols. Sometimes, the users and my informants did not have useful interpretation to offer for certain symbols or ritual behaviour. For instance, sometimes when I asked a group of celebrants; "why do you perform such ritual"? They replied: "Because our forefathers did so". To surmount this difficulty I adopted two other methods.

The first was the use of analogy. This involved interpreting ritual actions or objects by reference to other acts or objects which shared partial likeness or agreement with them, and whose meanings were well known and established.

An example here is my attempt to interpret the ritual behaviour in which women hit their knuckles on the ground after prayer. I likened it to the ritual behaviour of the owhor holder who hits his owhor on the ground after prayer, and concluded that if owhor is a male ritual symbol the knuckle is its female counterpart.

The second approach was to examine the "operational meaning", to use Turner's terminology, of the function of ritual symbol by pairing its meaning with its application (V. Turner, 1965; 80). By this I mean not only what the people say about it but what the people do with it.

\section{The Isiokpo Background}

We may now briefly turn to the Isiokpo, one of many village-groups making up Ikwerre, a people living on the north-eastern fringes of the Niger Delta, Nigeria.

The economic life of Isiokpo is strongly influenced by its natural environment. The latter is endowed with a fertile and cultivable area of land. Hence the people are mainly agrarian, and their chief occupation is farming. Yam, the chief of crops, is primarily the concern of men; whereas, cassava, maize and vegetables are cultivated by women. Although farming is the major occupation of the Isiokpo, some combine it with or specialize in fishing, trading, hunting, tapping of palm wine, carving or other activities of magico-religious nature (G.I.K Tasie, 2005:43).

As regards their spiritual life, Isiokpo people see every facet of human activity and of the environment as underpinned by one spiritual agent or another. Different zones of the habitat are seen as controlled by 
different categories of spirits with different characteristics and functions. The individual is protected by his or her Chi. Besides Chi there are other deities concerned with the welfare of the individual. Thus Ikenga, Amadioha and Agwumagwu are concerned with male achievement, while Eku is concerned with female prowess in cooking and the matrimonial arts generally.

Next to these deities, the category of spiritual agency closet to man is that of the ancestors, Nda madu. Not only are the ancestors recruited from amongst the птио (souls) of human beings who have departed from their bodies after death, they in turn provide from amongst their number the nтио of new generations of human beings. Nda madu are considered to have a keen interest in the affairs of their patrilineal descendants.

Perhaps the most important deity in the life of the Isiokpo is Ali, the earth deity. Ali is the sustainer of social groups at all levels, and is angered by anything that threatens the unity and harmony of such groups. Hence she is seen as the ultimate guardian of the Isiokpo moral code.

The forests are control by predominantly malevolent spirits; and the rivers are controlled by Ngwuluo and other fairly benevolent but morally neutral spirits (see G.I.K Tasie. 2005).

\section{Isiokpo Concept of Symbolic Action}

Symbolic objects and actions, as we are to see later in this essay, feature prominently in Isiokpo rituals and even in arts, myths, folk tales and in everyday sayings; yet the language of the Ikwerre seems to contain no exact word which corresponds directly to the English "symbol". However, there are numerous partial equivalents. Two examples will suffice. Amaa is an Isiokpo word whose synonyms in English could be signal, warning or revelation. For example, the Isiokpo say; ogwu gbaru amaa rie nye okwu nkee ("The war which issues a signal does not claim a one legged man"). This saying has a variety of meanings. But in a sense it may mean: to be forewarned is to be forearmed. Thus the hitting of one's left foot against an obstacle is a sign of an impending misfortune which may warrant divination to determine which spirit agent has been wronged and what ritual action is required.

Another word which closely resembles the English "symbol" is noseaya; whose English equivalents may be to represent, to substitute, to stand for, to pose as, etc. Thus in rituals the son in the absence of his father can effectively stand for or represent the former. In the same vein, a sorcerer may make a representation of a person in wood or stone and whatever harm that is meted out to the effigy is believed to befall the person at that instant. Similarly too, a medicine man in a placatory ritual can offer a doll to the spirits as a substitute for the life of an afflicted person.

What conclusions may we draw from these findings? First of all, a symbol in Isiokpo thought is a kind of representation; but it is also more than that when it occurs spontaneously, it can foretell the occurrence of that which it represents. Again, when it is deliberately used by a human agent or agents, it can bring about that which it represents. In sum, it is seen as having representative, predictive and causal powers.

\section{Types of Symbol in Isiokpo Ritual}

Although the various spiritual agents, as we noted earlier, have their domains in the spiritual world, their activities nonetheless impinge on the life of man in the visible, tangible world. Hence the numerous deities have to be constantly approached for expiatory, pacificatory or redressive purposes. In all such cases, symbolic objects and actions feature prominently. In what follows, I discuss these objects and actions and the interpretations which the Isiokpo attach to them.

\section{Spatial Symbolism}

In dealing with ritual objects and symbols it is important we began with space since it is in it that all objects exist. One important aspect of Isiokpo spatial concepts is their division of the local environment into two parts, namely mbu or ezi and ohia. Mbu or ezi refers to areas of human settlement. The deities most closely associated with this habitat are $C h i$, the deity associated with the existence and fortunes of the individual; $N d a$ $m a d u$, the ancestors; and $A l i$, the Earth deity. Mbu or ezi and its associated spirits are considered as essentially benevolent and all sacrificial items meant for them are deposited in their shrines, which are within the homestead.

On the other hand, ohia refers to uninhabited bush. Ohia in turn is divided into two parts, akwa aru, farmland and igbogo, uncultivated forest. It is on akwa aru, open palm bush that the Isiokpo rely for their livelihood. It is the abode of such beingn deities as Ajokwuji, the god of yam, Ali ibi the god of the farmland and Obu izor the god of the farm road.

Opposed to akwa aru is igbogo, which is an area of tall trees and dense undergrowth. Igbogo is not only the abode of wild animals with their incessant and strange noises but also the dumping ground of the bodies of the evil dead and the wandering place of malevolent spirits. As a result igbogo is considered fearful and has an evil connotation. 


\section{Temporal Symbolism}

In rituals, the Isiokpo consider very seriously time of day which to them is impregnated with meanings and therefore dictates when certain rituals are to be observed. Thus ishi ortutu or ishi obochi (early morning) is believed to be the departing time of ancestral spirits and other benevolent deities who had visited the abode of the living in the course of the night. At this time of the day medicine men offer sacrifice to them either for expiatory, pacificatory or redressive purpose which they are expected to carry back home to the spirit world. Those who are bedeviled with sickness or misfortune equally find this time of the day appropriate to claim their innocence and solicit the help of the ancestors and other benevolent spirits as they will hear their supplications on their way back to the spirit world.

On the other hand, etiti ehihe (mid afternoon) is the time when evil and malevolent spirits roam about in search of people to hurt. This time of day is vicious and it is the period when harmful magical rites are performed. Since it is the time evil and malevolent spirits go roaming the Isiokpo never bury their dead at noon. For they believe that the ghost spirit of the deceased may have the misfortune to meet them on its way to the spirit land.

Anya asu, evening, is considered benign and it is usually a period when rituals, especially those aimed at promoting good health, peaceful co-existence and wealth, are carried out. This probably stems from the Isiokpo sayging that owha anyasu kanma ("Evening world is the best"). Which by implication means that to live well and enjoy life at old age is better than to start life in affluence and end up in squalor. Generally, therefore, the Isiokpo consider evening and all its associated spirits as essentially benevolent. Etiti abili (midnight) on the other hand conjures up a sense of awe similar in many ways to mid afternoon which I have earlier discussed.

The traditional week is made up of four big days and four small, making eight in number i.e. Eke Ahia, Irie Ku, Awhor and Nkwo Ali, the big days and Eke Ejibara, Irie Wejibara, Awhor Abia Eke, Ahia Eke, the minor days. The big days are symbolic because it is on such days that most of the deities are worshipped. Eke Ahia is the most symbolic of the days; not just because it is the first day of the Isiokpo week, but because, it is the day set aside for the worship of Ali, the Earth deity, the most important deity in the life of the Isiokpo, Nda $m a d u$, the ancestors and other patron deities. Thus Eke is sacred and is the traditional resting day of the people. On this day no strenuous job is performed in the farm.

Months (onwah) are reckoned by the waxing and waning of the moon. Ten months make up a year in Isiokpo calender. The various months are correlated with the various activities of the agricultural cycle. Of particular interest is onwah asa (the seventh Isiokpo month). The month marks the end of the farming season. This, however, only means that cultivating and planting with the hoe have come to an end. The Nye na kwa Ali of Isiokpo (the priest of the earth deity) formally announces the end of the farming season in a ritual known as okporo. Within this month too, some of the yams in the yam farm are considered mature, a condition which is indicated by the withering of their hitherto luxuriant green leaves; and farmers begin okeji ike (selective harvesting of mature new yams). Outside its agricultural implications onwah asa is symbolic in one other respect. It is the month in which evil people die.

\section{Colour Symbolism}

Certain rituals attract certain colours which are very symbolic. Three colours, ochasi, white, onunu, black and ihie, red, feature prominently in Isiokpo rituals. Ochasi, symbolizes ritual purity and innocence. Опипи is a symbol of mourning and bereavement and ihie is a symbol of danger.

\section{Number Symbolism}

Numbers too, are equally symbolic; and numbers three and four are particularly symbolic especially in the breaking of kolanut. A kolanut with three lobes is considered as ritually impure and is believed to bring bad fortune, whereas, one with four lobes is ritually pure and a symbol of good fortune.

\section{Symbolism of Vegetable Materials}

Certain plants and vegetable materials are also symbolic. Prominent among them is the owhor and its adjunct $o g u$. Owhor is a sacred piece of stick, a branch of the Detarium elastica tree, believed to be imbued with spiritual and/or ancestral power.

There are family owhor, lineage owhor and even village owhor. However, there are other types of owhor used by medicine men, diviners and priests. C.I. Ejizu (1986:35) describes these as professional owhor. Owhor is predominantly used by men during rituals. The hitting of the owhor on the earth symbolizes the sealing of prayer or curse as the occasion may demand. Owhor symbolically denotes justice and authority.

$O g u$ on the other hand is smaller than owhor and both are believed to possess a mystical power which exonerates the innocent. $O g u$ stands for the cause of moral uprightness. When one is afflicted with inexplicable ailment or when evil dogs the life of an individual, the medicine man, before he commences treatment admonishes him/her tu ogu ("claim your innocence"). This is because many sicknesses are thought to result 
from wrongs against the deities or as inflicted by a sorcerer. Until one's offence is established and the deity accordingly placated, the drugs of the medicine man will never be efficacious. The individual claiming his innocence will carry his ogu or in its absence may pick a piece of fire wood which symbolically represents the $o g u$ and intermittently hit it on the ground as he says:

Ali Isiokpo ndam

Ndam ele ke leru ala

Akam zi ocha

Oza madu megburu

Oza agbara me riri nhe ah

Nye no gbum ehwe ehu

Aka kwa nu igwu owhiriwha

Ochi nwo okwukwu nwe adda

Nwo okwukwu nun nwho

Nwho asor

Another remarkable plant material is the оти nku, the tender oil palm frond, (Elaeis Guineensis) known for its multiplicity of purpose. Within sacrificial context omu $u k u$ is regarded not only as a symbol of purity but also as capable of warding off evil influence, not only from the sacrificial items, but also from the celebrants. Thus in a cleansing ritual a piece of oти nku beaten on the body of a defiled person restores purity. On the other hand, when pieces of omu nku are hoisted around a shrine they conjure up a sense of sacredness and at the same time are believed to be imbued with power to repel unwanted spiritual forces. Similarly, as part of preparation for a funeral, there is the need to fortify fruit trees in the homestead, where death has occurred, against the influence of the corpse. They are tied round their trunks with omu $n k u$ to protect them from withering. Also strips of оти nku are tied round ojo (an elevated platform built for the purpose of laying the body of an owhor holder out in state); they are believed to be endowed with the power of protecting the corpse from evil influences. P.A. Talbot (1967:246) further suggested that oти nku seems intended as a symbol of rebirth to the bereaved family. Some masquerades too hoist omu $n k u$ on their mask. The purpose is to fortify them against the evil machinations of rival masquerades.

Outside its religious symbolizations оти $n k u$ also communicates a lot of other messages. The hoisting of omu $n k u$ on a piece of land, as I noted earlier, denotes that the said piece of land is in dispute and therefore serves as warning to the party in dispute not to enter until the matter is resolved. Oти nku is also used as a symbol of danger. Like our present day danger sign of skull and cross-bones, оти nku is hosted along major roads to alert road users of gullies and other dangerous spots so that appropriate precautionary measures could be taken.

One other remarkable message which oти nku conveys is that of solidarity. In the not too distant past when cultural troupes displayed wild masquerades which chased people around with machete and whips it was customary for people to obtain a piece of оти nku with a little sum from members of the masquerade group. One who had obtained such piece of оти nku raised it up at any point he met any of the fierce masquerades. This was to say that he meant no harm and was in complete solidarity with the troupe.

Ikeni leaf (Detarium Senegalense) is another plant material which also features prominently in rituals. It is commonly used by medicine men and it is on it that ritual objects are placed. The Isiokpo say that ikeni symbolizes strength. When used in ritual or in the preparation of medicines it confers potency on such preparations.

If ikeni is a symbol of strength, abosi (Baphia nitida), on the other hand is a symbol of discord and enmity. Among the Isiokpo it is not uncommon for friendship and kinship ties to be broken off after a quarrel. To sever such a relationship abosi leaf is torn between the disputing parties. This symbolizes enmity which persists until a reconciliatory ritual known as obubu оnи is performed.

In rituals aimed at dissuading an ogbanje child from repeated calls, ogbakala (oil bean seed) features prominently. Ogbanje spirits are group of adventurous evil spirits who are on a visit to the human world. They arrive in the human world via earthly parents. These spirits are under pact with themselves as to how long each of them will stay on earth. They come, raise the hope of their parents then at the expiration of the term of their agreement, they depart. When an ogbanje child dies, the corpse is buried faced down (with the belief that in that position it cannot find its way back to the homestead) with oil bean seed placed by its side. The oil bean is a tropical plant whose seeds grow in pods. When a pod is fully mature, it explodes when heated by the sun scattering its contents in different directions. Here, the seed is a symbol of dispersion, indicating that the ogbanje child is no longer wanted and should stay far away.

Of similar symbolization is opoli (gunpowder) which is used to drive away ghost-spirit from the homestead. If a ghost-spirit becomes malevolent and haunts the living, a dibia (medicine man) is invited to scare it out of the homestead by a ritual cannon shot or the ritual lighting of gunpowder. The cannon shot scare the 
malignant spirit away from its living kith and kin. The lighting of gunpowder severs ties between the ghost spirit and its kins folk causing it to stay far away.

\section{Symbolism of Human Body Parts}

Different parts of the human body often assume rich symbolic significance in ritual contexts. Human hair feature frequently in rituals. The most established ritual use of hair is it association with mourning. Here shaving of head hair symbolizes bereavement and mark of respect for the deceased and wearing of long hair by the widow is a symbol of mourning to this I will return presently. However, there are a host of other uses to which the hair is put by medicine men. Although the human head is not the seat of the soul, head hair is particularly useful in magic rituals, especially those intended to cause mental disorder, increase or diminish wisdom. This is perhaps due to the sacred nature of the head and the belief among the Isiokpo that the head is the seat of reason. Like head hair, pubic hair is equally symbolic and important in certain rituals. By association, pubic hair is linked with the vulva and phallus both of which have direct relationship with fertility. Therefore it could be employed in magical ritual aimed at causing fertility or impotence. Outside its use in magical preparation head hair also has other symbolic values. Unkempt long hair symbolizes being outside society. By this I mean having not much to do with society. For instance, a person who has sworn an oath is subjected to a probationary period of one year within which the deity on whose name and emblem he has sworn is expected to pass judgment. Within this probationary period, the individual is forbidden to cut his or her hair. $\mathrm{He} / \mathrm{she}$ is ritually impure and separated from society. At the expiration of the one year if he/she does not die then innocence is established. The hair is cut and the individual is declared innocent and pure and readmitted into society.

The same treatment, as I earlier noted, is also meted out to a widow. After the funeral rites of an owhor holder his widows begin a one year period of mourning. The demands of this period are very stringent for the widows. They are surrounded with innumerable regulations and taboos, prominent amongst which is that they are never allowed to cut their head hair. Within this period also they are forbidden to remarry because they are considered impure and separated from society. However, at the end of the one-year mourning period, omecha $a h u$, a rite of purification and rebirth, is observed and the hair is cut. This restored them to their former position. They are once more pure and normal people and readmitted into society. Here, unkempt long hair symbolizes separation from society and state of impurity, whereas, hair cutting symbolizes readmission into society and a rebirth.

As with the hair other parts of the human body such as nails, blood, semen, vestiges like shadows and even things that an individual was once in contact with such as personal garments and foot-prints are considered as extensions of the person. Hair and nails are considered very seriously in magic as the symbol of the whole person. This may stem from the Isiokpo belief that, like the whole body, hair and nail grow constantly and are endowed with vitality. As for blood, it symbolizes the worth of the individual person and his link with his kin group; and semen in the eyes of the people symbolizes the water from which life flows.

Another remarkable part of the human body with rich symbolization is the knuckles. If the owhor is a male ritual symbol, then the knuckles are exclusively used by the female. As with the owhor, the hitting of knuckles on the earth by women after prayer symbolizes the sealing of the prayer or curse as the occasion may demand.

\section{The Symbolism of Carved or Constructed Images}

Also of great symbolic importance are carved or constructed images which are found in the ancestral cults and rites relating to them. Remarkable among them is the Nda madu, the ancestral emblem. The ancestral emblem symbolically represents the ancestor on whose behalf the emblem was carved. The emblem is addressed as "our father" and is the focal point of all ancestral rites and all venerations are addressed to it. The emblem of the $N d u$ madu is attired with different accoutrements which are very rich in meaning. Thus the emblem is dressed in george wrapper upon chieftaincy gown with ogbu wagoro (traditional cap) on which is pinned an eagle feather and a walking stick by its side.

These symbolize the enviable position which the honoured dead occupy in the hereafter. The george wrapper is a symbol of status and wealth. The eagle's feather which is pinned to the traditional cap is a symbol of strength and also of high status. So Nda madu is an embodiment of strange powers which are made manifest in avenging the breaking of oaths sworn upon its symbol. This enhanced power is brought about by the event of death coupled with the activation of the ancestor cult which confers on the Ndu madu, as it were, the status of a deity.

\section{Other Artifacts and Non-Biological Materials}

Certain rituals, especially those aimed at redeeming one possessed by spirits, demand certain ritual objects which are richly symbolic. These objects include dolls, coins and abii (manilas), which after the ritual 
may be deposited at a road junction. The doll symbolizes the possessed person and acts as a substitute which is given in exchange for him. The abii and coins denote wealth but when used in placatory rituals act as ransom aimed at freeing one who is possessed. As regards the road junction, it is generally believed to be the meeting place of evil spirits.

Among medicine men, there are certain ritual objects which are indispensable. Prominent among them are odo (native yellow chalk) and oro (kaolin clay). Odo denote understanding. When rubbed across the eyes or used in rituals odo enables the medicine man to see clearly into the spirit world and bestows on him wisdom in carrying out a ritual. Oro, on the other hand, is a symbol of purity and also denotes tranquility and helps to create the necessary atmosphere of quietude required for a ritual.

\section{Symbolic Significance of Ritual Gesture and Behaviour}

Finally, let us turn to certain ritual behaviours, gestures and omens which feature regularly in Isiokpo rituals. It is not uncommon for the medicine man before he hands over his preparation to his patient to make a gesture of spitting at the preparation and to add a pinch of earth to it. This ritual attitude, the Isiokpo say, is aimed at conferring potency on the preparation and perhaps to beg $A l i$, the earth goddess, who is considered the most important deity in the life of the Isiokpo, to bless the preparation.

This brings to mind yet another ritual attitude closely associated with the Earth deity. Among the Isiopko, if a child accidentally slips from its mother's hand and falls to the earth, the mother quickly reaches for the child, then touches the earth with her palm and rubs it on the baby's head. As she does this, she addresses the earth: Ali igbuoo! Obu nwoji. (Earth do not kill, it is your child). This symbolizes the belief that Ali is most generally (though not invariable) thought of in feminine terms not only as the wife of her chief priest but also as the mother of all ordinary Isiokpo people.

Now in certain rituals especially those aimed at freeing one who is under the influence of a spirit, the sacrificial objects are passed round the head of the patient before they are finally dumped at a road junction. Here, this ritual attitude is a symbol of exchange of the patient with the sacrificial objects. The head symbolizes par-excellence an individual person. For the Isiokpo, as I have earlier noted, the head is the seat of reason and has a very close connection with the heart, which the people say is the seat of the soul, the human essence. Even in everyday Isiokpo speech a head is metaphorically used to denote a person.

However, some rituals may not demand passing the sacrificial items round the head of the patient. Rather branches of certain trees or leaves are used to ritually beat the patient from head to toe and are then thrown away. This ritual attitude signifies that the sins of the individual have been transferred to the branch and it has now come to bear the punishment which hitherto was earmarked for the patient. By throwing it away to the spirits it has been given in exchange for the patient and acted as ransom to free him.

Immediately such a ritual is completed and the sacrificial items dumped at a road junction or any other place the medicine man may deem appropriate, the celebrants, as they begin their homeward journey are instructed by the medicine man not to look back. This compels them to walk briskly and solemnly, ignoring greetings from passers-by. A possible interpretation for this ritual attitude could be that to look back symbolizes willingness and desire for the misfortune which has been symbolically dumped with the sacrificial items. To look forward, therefore, symbolizes a complete severance of ties with the past.

\section{Conclusion}

To conclude, something needs to be said about the kinds of relationship that Isiokpo take as establishing connections between symbols and what they represent. Our analysis of Isiokpo ritual symbols seems to suggest two such kinds: resemblance and part-whole relationship. The Isiokpo place great emphasis on the resemblance between two objects, processes or events as the determinant of a symbolic relation between them. On the strength of this, they affirm that a carved doll is a perfect human replica and in ritual could effectively make a good representation of a person. On the part-whole relationship, there seems to be a belief that in some circumstances a part can adequately symbolize the whole. A good example here could be that of the human head. For the Isiokpo, as I earlier noted, the head symbolizes par excellence an individual person. Even in every day Isiokpo speech the head is metaphorically used to denote a person.

Finally, as we noticed, Isiokpo symbols are not mere representations or labels. They are seen as capable of affecting the objects they symbolize.

\section{Bibliography}

[1]. Abraham, W.E. (2005), The Mind of Africa, Chicago: University of Chicago press.

[2]. Ejizu, C.I. (1986), Ofor: Igbo Ritual Symbol. Enugu: Fourth Dimension Publishers

[3]. Fernandez, J. (1974), "Mission of Metaphor in Expressive Culture" in Current Anthropology No. 15, vol. 2.

[4]. Firth, (1973), Symbols: Public and Private. Ithaca, New York: Cornell University Press.

[5]. Geertz C. (1973), The Interpretation of Culture.s New York: Basic Books Publishers. 
[6]. Idowu, E.B. (1973), African Traditional Religion; A Definition. London: SCM press.

[7]. Jacob, P. (2009), Symbols: Meaning and Uses. Pretoria: Jack and Johnson.

[8]. Tasie G.I.K. (2005) "Between the Farm and the Market: A Study of the Impact of Belief System on Occupational Choice among the Isiokpo on Afe: Journal of Minorities Studies Vol. 7 No. 1

[9]. Leach E.R (1978), "Ritualization in Man in Relation to Conceptual and Social Development" in W. Lessa and E. Vogt (eds.), Reader in Comparative Religion. New York: Harper and Row.

[10]. Ortner S.B. (1973), “On Key Symbols" in American Anthropologist Vol. 75, 1973.

[11]. Kegan, G. (2008). Rethinking Symbolism. London: Smith Brothers.

[12]. Turner, V. (1965), "Ritual Symbolism, Morality and Social Structure among the Ndembu" in M. Fortes and G. Dieterlen (eds.), African Systems of Thought. London: Oxford University Press.

[13]. Turner, V. (1964), Symbols in Ndembu Rituals", in M. Gluckman (ed.) Closed Systems and Open Mind: The Limits of Naivety in Social Anthropology. London: Manchester University Press.

[14]. Turner, V. (1967), The Forest of Symbols. London: Cornell University Press.

[15]. Turner, V. (1975) 'Symbolic Studies', in Annual Review of Anthropology, No. 4.

[16]. Talbot, P.A. (1947), Tribes of the Niger Delta, London: Frank Cass. 